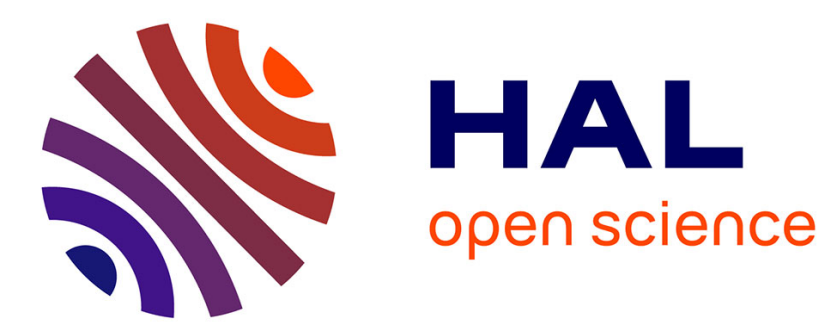

\title{
The new political economy of regulation
}

Cyril Benoît

\section{To cite this version:}

Cyril Benoît. The new political economy of regulation. French Politics, 2019, 17 (4), pp.482-499. 10.1057/s41253-019-00093-7 . hal-02356384

\section{HAL Id: hal-02356384 \\ https://hal-sciencespo.archives-ouvertes.fr/hal-02356384}

Submitted on 11 Oct 2020

HAL is a multi-disciplinary open access archive for the deposit and dissemination of scientific research documents, whether they are published or not. The documents may come from teaching and research institutions in France or abroad, or from public or private research centers.
L'archive ouverte pluridisciplinaire $\mathbf{H A L}$, est destinée au dépôt et à la diffusion de documents scientifiques de niveau recherche, publiés ou non, émanant des établissements d'enseignement et de recherche français ou étrangers, des laboratoires publics ou privés.

\section{(1) $(1) \Theta$}

Distributed under a Creative Commons Attribution - NonCommercial - NoDerivatives| 4.0 


\title{
The New Political Economy of Regulation
}

\author{
Cyril Benoît* \\ Working Paper (this draft: September 2019)
}

\begin{abstract}
Over the last twenty years, the study of economic regulation has attracted growing attention in political research. But what is so political about regulation? And what is 'new' in the political analysis of this topic? We argue that the answer to both of these questions lies in the evolution of the conception of regulatory power in political research. To validate this claim, we first review the main developments that followed the introduction of agency-theoretic models in this field. While recognizing their insights, we argue that these contributions rest on a narrow, essentially directive conception of regulatory power. With regard to more recent developments, we then show how a focus on other facets of the politics of regulation has connected it to broader political science questions. This focus significantly improves our understanding of regulation's influence on economic activities, public policy, and ultimately, on the politics of economic regulation in the broadest sense of the term.
\end{abstract}

${ }^{*}$ CNRS - Sciences Po. Contact cyril.benoit1@sciencespo.fr 


\section{Introduction}

Since the mid-1980s, the spread of neoliberal ideas has paired with significant changes in the governance structures of capitalist economies. Western countries have transferred ownership of key industries to the private sector and have developed regulatory supervision over their activities - mostly through independent regulatory agencies endowed with statutory powers (Yeung 2010). This bureaucratic form also diffused in a number of other economic areas in the course of the following decades. In this context, a large body of research has established that states have becoming increasingly "preoccupied with the regulation part of governance", in the sense that they now tend to prioritize "steering the flow of events", as opposed to directly influencing economic activity through unilateral actions (Braithwaite 2011). Much attention has been paid to the study of "the making" of this "new regulatory order" (Levi-Faur and Jordana 2005b), of so-called "regulatory states" (see for e.g. Majone 1994; Hood et al. 1999; Moran 2003) and of the global diffusion of "regulatory capitalism" (Levi-Faur 2005; see also Jordana and Levi-Faur 2006). These extensive transformations also gave rise to renewed interest in political research for the study of regulation not only as a mere form of governance but also as a concrete form of intervention by public-sector actors in economic activities (Koop and Lodge 2017; see also Baldwin et al. 1998). In contrast with the aforementioned contributions, these works usually involve fine-grained analysis, focusing on how bureaucratic agents regulate firms or other organized interests, usually on behalf of a political principal. Until recently, regulation in this narrower sense has traditionally been considered the most obvious, albeit less sophisticated type of coercion available to government (Lowi 1972).

However, new waves of research dating back to the early 1990s have gradually discovered how this topic lends itself to addressing broader questions. This trend amplified in the following decades with the forging of more subtle and complex networks of regula- 
tory instruments, alongside the rise of regulatory states (see Baldwin et al. 2012). This contribution is primarily a discussion of the findings that followed this move towards a more substantial study of economic regulation. More fundamentally, it highlights a gradual extension of the definition of regulatory power in the literature. Power is indeed the central dimension of interest for any student of economic regulation - the power of a firm over a regulator (and vice-versa); the power of organized consumers, the media, and third parties throughout the regulatory process; the power of politicians over a regulatory body, and so forth. In short, our main argument here is that research has gradually shifted from an essentially 'directive' conception of regulatory power to increasingly integrate its 'gatekeeping' and 'conceptual' facets. A large body of literature has emerged to investigate a wider range of political science themes through the lens of economic regulation, ranging from the foundations of state legitimacy and of bureaucratic accountability, interdependence between public and private bureaucracies, and relations between politicians and regulatory bodies - among many other subjects, some yet to be explored. Formally identified and defined by political scientist Dan Carpenter (2010a), the directive, gatekeeping and conceptual conceptions of regulatory power are thus used here both for classification and analytical purposes.

Directive power refers to a "broad formal authority to direct the behaviour of others" (ibid). In a way, it is the form of power that has dominated the study of economic regulation for decades. Without jettisoning this conception, a generation of scholars has used agency theory to offer more comprehensive approaches to studying the politics of regulation. This development notably helped widen the range of actors included in research on economic regulation to include legislative bodies, legislators, executives, and courts. A second wave of studies developed finer conceptions of regulatory power in the 2000s and 2010s. A growing body of research started to study it as an ability for regulation to 
"define what sorts of problems, debates and agendas structure human activity", namely its 'gatekeeping' dimension (Carpenter 2010a). Instead of presenting regulatory bodies as vacuums across which political, industrial, and other special interests transited, scholars started to investigate the "forging" of bureaucratic autonomy (Carpenter 2001) - and in turn, the implications of such autonomy for regulators' legitimacy and ultimately, to shape public policy or embody state legitimacy.

The 'conceptual' nature of regulatory power was then increasingly acknowledged. In its broadest sense, this term refers to regulatory agencies' and regulators' ability, sometimes in the very course of the regulatory process, to "shape the content and structure of human cognition itself" through a variety of standards and ideas (Carpenter 2010a). More specifically, it refers to the ability of regulators to require that various private actors use a diversity of concepts and metrics in their daily activities. As they become ingrained in everyday business practices, regulatory concepts help change the perception of public problems and usher new behaviours. In a number of respects, this process shares similar features with those identified by research on state development (see King and Stears 2011). We believe that such transformations of the field justify this article's title - the new political economy of regulation. This is not to suggest that the literature now resembles a theoretical monoculture. The different contributions presented in the following pages admittedly display considerable variations. Still, we think that a higher level of analysis enables the identification of a twofold novelty in relation to pre-1990s studies of economic regulation. First, the research on economic regulation now considers a large and complex set of collective and individual actors. Second - and more fundamentally substantial refinements of the conception of power have shaped contemporary studies in the field. As such, these contributions ultimately helped shed light on the relationships between various governing and governed entities in the age of regulatory governance. 
The rest of the paper is organized as follows. Section 1 introduces the main developments in the study of the politics of economic regulation between the 1980s and 1990s. We particularly emphasize the different contributions made following Laffont and Tirole (1991). Section 2 reviews more recent developments in the field, and shows how greater interest in the gatekeeping and conceptual facets of regulatory power helped connect research on regulation to other segments of political research.

\section{Regulation as a Directive power}

\subsection{Insights from Laffont and Tirole}

Regulation as a public-sector driven intervention in economic activity belatedly emerged as a specific subject of inquiry for political research. This is not to say that political scientists had previously completely ignored the topic, or that their contributions were unhelpful to our understanding of the relation between states and corporations in this domain. Indeed, several publications touched upon it, especially in the 1960s and the 1970s (see for e.g. Lowi 1969). Yet, until the end of the 1980s, political science was rarely interested in economic regulation per se. As a result, it had not developed a specific framework to study it. Economic regulation in political science was thus long seen from the vantage point of general theories of political decision-making or public policy choices (Downs 1957; Buchanan and Tullock 1962), and later, bureaucratic politics (Niskanen 1971). Unsurprisingly, the study of economic regulation was more mature in the field of economics.

In their study of regulation, economists have traditionally focused on two main research questions. The first relates to the "role of affected [industrial] interests in [the design of] regulatory policy and administration"; the other is the extent to which "regu- 
latory administration balances the public interest against regulated interests' in its daily activities (Christensen 2011). Two main answers were provided to these questions between the post-war period and the end of the 1980s, namely public interest theory and capture theory.

Public interest theory, which significantly developed after WWII, essentially focuses on the role of government in correcting various market failures (see Hankte-Domas 2003 for a discussion). It rests on two general assumptions. The first is that market failures recur due to monopoly pricing issues and environmental externalities. The second is that governments are fully able to correct such failures through appropriate regulatory instruments. This can be done by imposing "control prices so that natural monopolies do not overcharge, safety standards to prevent accidents such as fires or mass poisonings, regulate jobs to counter the employer's monopsony power over the employee" and so on (Shleifer 2005). A key point here is that the public interest theory of regulation rests on the general premise that regulatory agencies "are viewed as benevolent maximisers of social welfare" (Laffont and Tirole 1991). As such, public interest theory rarely investigates the politics of regulatory decision-making per se, since these are considered implicitly benign. Market failures remain the central focus of the analysis, the main goal being to help carefully design the shape and scope of much-needed public interventions.

An alternative approach - capture theory - emerged in the 1970s as a critical response to public interest theory. One of its most renowned proponents, the Chicago economist George Stigler, claimed in his seminal 1971 article that public interest accounts take an "idealistic view" of regulation (Stigler 1971). The state, Stigler argued, is better understood as a "potential resource or threat to every industry in the society"; as such, industries continuously and purposely use it "to improve their economic status", creating a permanent "demand for regulation" - including subsidies, control over competitive 
entry, regulation of product substitutes, and price fixing (ibid). In parallel, industries and interest groups may provide policymakers with a range of benefits to gain their support, such as monetary bribes, employment with the regulated firms, and political campaign contributions (see Laffont and Tirole 1991) - although these may only be the "tip of the iceberg" (Tirole 1986). According to Stigler, this observation cast doubt on the rationale for regulation, and the likelihood that state agencies are benevolent maximizers of social welfare. Building on recent advances in political science - notably Olson (1965) - he emphasized the role of industry itself in the formation of regulation, arguing that "regulation is acquired by the industry and is designed and operated primarily for its benefit" (Dal Bó 2006). As the first positive theory of economic regulation, (Veljanovski 2010), capture theory was a bedrock. It reshaped "economists' thinking about regulation, making the case for analysing regulators' behaviour using the same kinds of theories and methods economists use to analyse any other producer and consumer behaviour" (Carrigan and Coglianese 2015).

Capture theory paved the way for further examinations of economic regulation. But it rests on an excessively simple conception of governmental decision-making. Its many weaknesses (see further; Carpenter 2014) include a general failure to account for the complexity of institutional games, as it ignores a number of information asymmetries between the different players (politicians, regulators, firms) involved in such processes. More fundamentally, the proper behaviour of the regulatory agency is insufficiently considered. Some of these shortcomings were properly identified and addressed by Laffont and Tirole $(1990 ; 1991 ; 1993)$ and Tirole $(1986)$, who introduced an agency-theoretic approach to economic regulation. Their contribution is certainly one of the most important ones in the mathematical conceptualization of regulation in recent decades. This framework also rapidly spread to political science, at least in the U.S. As compared to prior 
studies of economic regulation, Laffont and Tirole's main insight was to analyse regulation as a principal-agent problem involving a bureaucratic agency (the 'supervisor'), a political principal ('Congress'), and a firm. This three-tiered model fully integrates "the productive inefficiency associated with asymmetric information and insurance motives" (Tirole 1986)1 . It thereby considerably complexifies the problem presented by Stigler, since it better reflects the internal differentiation that exists within each government apparatus between political and bureaucratic functions (see also Noll 1989). In addition, "the extra player (the regulator) allows one to analyse how the political principal might want to respond to the risk that its delegate may be captured" (Dal Bó 2006).

On this basis, Laffont and Tirole notably show that the "organizational response to the possibility of regulatory agency politics is to reduce the stakes interest groups have in regulation"; moreover, "an interest group has more power when its interest lies in inefficient rather than efficient regulation, where inefficiency is measured by the degree of informational asymmetry between the regulated industry and the political principal" (Laffont and Tirole 1991) - not to mention various other inputs exposed in Laffont and Tirole (1993), notably for the regulated firms. The principal-agent framework ultimately helped identify a range of potential responses by the political principal, by showing how "asymmetric information is the source of regulatory discretion" (Dal Bó 2006).

More fundamentally, the general model developed by Laffont and Tirole helped significantly expand the conception of regulation, as a process made of strategic interactions involving political actors, regulator(s) and (a) firm(s). They also showed that the politics of regulation was also - and perhaps first and foremost - the politics of information.

\footnotetext{
${ }^{1}$ In the study of regulation and bureaucratic politics, these problems essentially relate to moral hazard, when the agent "is privy to some information that the principal needs to make a decision in her own interest" but prefers "that the information be used differently" (Gailmard, 2014; see also Arrow, 1985); and "adverse selection", which refers to the political principal's difficulty to select the agent with the appropriate abilities and preferences (Kiewiet and McCubbins, 1991).
} 
This perspective heavily contrasts with public interest theory, which largely ignores the role actually played by government institutions; and with capture theory, which rests on a monolithic conception of government decision-making.

Economists' understanding of the politics of regulation has thus considerably evolved over the past forty years. Following Laffont and Tirole, a number of publications examined "the complications that arise when regulated suppliers have better information about the regulated industry than do regulators" (Armstrong and Sappington 2007). A series of significant improvements to Stigler's basic conception were made, "allowing for the interplay of multiple groups exerting influence on policymakers and multiple motivations on the part of policymakers themselves" (Carpenter and Moss 2014). During the 1980s, the growing diffusion of agency theory in economics sparked political science's in-

terest in the study of regulation, first in the U.S, and then in Europe. While they rest on a similar framework as those developed by their economist counterparts, these political science contributions differ from them in many ways. First, they pay more attention to the institutional dimensions of the regulatory process, namely to the role of legislative bodies and other political principals. They also tend to focus less on firms' behaviour, and on the implications of regulation for the regulated industry. A third difference is that they tend to relax some of the assumptions of principal-agent accounts. The latter especially applies to qualitative studies of regulation that developed in Europe during the 2000s.

\subsection{Principal and Agent Centric Approaches to the study of Regulation}

Agency theory has long remained the gold standard in the study of economic regulation in political science, as suggested by the significant increase in the number of publications 
using this approach from the 1980s to the early 2000s This trend has paired with political research's growing interest in the study of economic regulation, although some differences, especially between American and European scholarships, exist.

The differences relate to the analytical focus and the use of principal-agent models. Indeed, interest in the study of the politics of regulation is anchored in different subfields of political science in the US and Europe, accounting for a number of dissimilarities (Benoit forth.). In short, students of American politics have focused more on the way political principals seek to control their bureaucratic agents than on the study of what agents actually $\mathrm{dd}^{3}$. This is due to the fact that most US contributions originate from the field of legislative studies, and more specifically from the study of the relationship between Congress and federal agencies. Their main research question is therefore to determine politicians' actual influence on bureaucratic behaviour.

In contrast, students of European politics have adopted principal-agent frameworks to study delegated agencies, which rapidly proliferated in Europe during the 1990s and 2000s. Most of these studies are agent-centric, since they do not dwell much on how political principals seek to monitor them. They essentially try to understand the interactions between agents and their broader environment, in order to assess the extent to which they are actually independent from various individual or collective actors. Rooted in the subfield of public policy and administration, these studies, unlike their American counterparts, are usually not based on general-equilibrium models of political control. They are essentially qualitative studies that use agency theory more as a heuristic element

\footnotetext{
${ }^{2}$ See Miller (2005); Maggetti and Papadopoulos (2018).

${ }^{3}$ A key concern for this literature is the way political principals mitigate "agency loss" when they delegate policy implementation to a bureaucratic agent. Scholars in the field are thus particularly attentive to the management of bureaucratic "drift" (when an administrative agency "pursues policies whose consequences diverge from social and/or legislative goals") and bureaucratic "slack" (that refers to "the tendency of agencies to pursue their mandates with insufficient effort, diverting resources from producing higher quality regulation") (De Mesquita and Stephenson 2007).
} 
than as a basis for formal modelling.

Unsurprisingly, these American-European contrasts have generated different inputs in the literature. Principal-centric approaches to the study of regulation in the U.S significantly developed in the 1980s and the 1990s. Until then, and following Lowy (1969) and Niskanen (1971) there had been a general consensus among students of American politics that Congress "had yielded up control over the apparatus of government to administrative agencies, which were in turn influenced [by a variety of special interests]" (McCubbins 2014). The "Congressional abdication" thesis was challenged between the 1980s and the 1990s by a number of researches informed by agency theory. Their major input was a demonstration of how legislators wield a range of discrete and subtle instruments to monitor their bureaucratic agents in regulatory agencies.

In an influential article, McCubbins and Schwartz (1984) argued that "Congress establishes a system of rules, procedures and informal practices that enable individual citizens and organized interest groups to examine administrative decisions (sometimes in prospect), to charge executive agencies with violating congressional goals, and to seek remedies from agencies, courts and Congress". Extending this statement, a number of statistical correlations have been established between changes in several agencies' behaviour and the changing preferences of Congress or its corresponding subcommittees. This is notably the case for the Federal Trade Commission and the U.S Senate, as studied by Weingast and Moran (1983). This finding was echoed by Weingast (1981; 1984), who showed that "Congress exercises systematic influence in several regulatory contexts, including airlines, communications and securities regulation" (Calvert et al. 1987). The delegation of regulatory prerogatives to federal agencies would therefore not reveal a loss of congressional power, but rather a different strategy for Congress to pursue its own political agenda (McCubbins 1985). 
Without denying Congressional attempts to control regulatory agencies, other authors have used principal-agent frameworks to stress that regulatory agencies have not one but multiple principals (see Whitford 2005). In his study of the National Labour Relation Board (NLRB), Moe (1987a) demonstrated that regulatory performance is affected by congressional committees, presidents, the courts, agency staffs, and constituents - all of whom have proven "to have significant impacts on NLRB decisions". These multiple sources of political influence are not all of equal importance, however: Moe (1985; 1987b) in particular argued that the presidency - and not necessarily a fragmented and divided Congress - was the actual political principal of regulatory agencies.

These studies associate diverse motives with politicians' interests in monitoring regulatory agencies, including responding to interest group pressure and to constituent demand, and partaking in important policy debates. Recent research suggests that the salience and technical complexity of the regulatory area also positively correlate with legislative attention (see Benoît forth. for a review). Still, students of American politics have paid relatively little attention to the study of bureaucratic agents per se (McCubbins 2014), in sharp contrast with the European literature on regulation that essentially emerged during the late 1990s. Though largely influenced by principal-agent accounts developed by Americanists (Pollack 2002), most European contributions have been authored by public policy and administration scholars who tend to take the perspective of the agent rather than the principa $4^{4}$

Some contextual factors explain this growing interest. Until recent decades, delegation to regulatory agencies was much more common in the U.S than in Europe. This situation rapidly changed in the 1990s and 2000s, when a number of independent regu-

\footnotetext{
${ }^{4}$ This is also due to the widely held view that European legislatures would pay significantly less attention to policy implementation than Congress does (Aberbach et al. 1981). Recent research shows that this statement could be misleading (Ennser-Jedenastik 2016).
} 
latory agencies were created in response to the liberalization of industrial monopolies such as railways, roads, and telecommunications, among many other sectors. In France, for example, Frison-Roche (2004) argued that the regulatory order was largely built on the ashes of an economic structure developed around state monopolies in charge of providing public goods. There are now 57 regulatory agencies in France alone, while Gilardi et al. (2006) identified 169 agencies across Europe and Latin America in 2002. The trend is similar in most European countries. It is worth mentioning that European integration has compounded this trend in many sectors by establishing supranational networks of independent agencies (Thatcher 2011).

As a result, comparative research has examined the process of delegation to independent regulatory agencies in Western Europe. These contributions briefly touch on political control, although they typically use less sophisticated models than their American counterpart: 5 . In a rare cross-sectional study featuring a relatively similar statistical apparatus, Gilardi (2008) showed that delegation is more likely to occur when governments in the 17 studied European countries need to strengthen the credibility of their regulatory commitments and when they attempt to tie the hands of their political successors. Using descriptive statistics on Britain, France, Germany, and Italy, Thatcher (2002) argued that regulatory agencies in Western Europe - contrary to their U.S counterparts - "enjoy considerable insulation from elected politicians in terms of party politicization and tenure".

However, and until the second half of the 2000s, the bulk of European scholarship has more focused on regulation as a broad form of governance than on the principalagent- industry relationship per se. For example, Levi-Faur (2014) has discussed the implications of the growing embeddedness of older forms of government activities - the

\footnotetext{
${ }^{5}$ See however Bach et al. (2018).
} 
Welfare state in his case - in regulatory agencies. Thatcher (2007) has wondered whether "different countries representing different 'varieties of capitalism' have followed distinct adjustment paths" to the regulatory state. He notably showed that regulatory agencies in France "have spread to a similar extent to Britain", representing a "sharp change" in the country. Another distinctive feature of European scholarship is its greater interest for the role played by regulatory agencies in their wider policy sector. Ossege (2016) has for instance compared how three European Union (EU) agencies (the European Medicines Agency, the European Food Safety Authority and the European Chemicals Agency) capitalize on their expertise to keep their autonomy in areas of high public salience. Without discussing the political economy literature on regulation, others have studied and compared the policy instruments of regulatory agencies (see for example Coletti and Radaelli 2013). This suggests that the agent-centric approach adopted by most students of European politics does not solely focus on regulatory agencies.

\section{The Gatekeeping and Conceptual Facets of Regulatory Power}

\subsection{Beyond Capture theory}

Economists' contributions on regulatory politics, and political scientists inspired by their frameworks in the early 2000s, covered diverse orientations and research topics. Still, they adopted a similar approach to regulatory power.

Indeed, the contributions share a virtually identical conception of the relationship between regulators and the regulated. From Stigler's writings to the mid-2000s, "the notion of the politician?regulator trading regulation for re?election in the light of interest?group 
demands for regulation" (Baldwin et al. 2010) predominated in most studies of economic regulation. Even when complex, the political analysis of regulation has long rested on the implicit assumption that the different participants in the regulatory game "are all subject to the same self-regarding goals as are assumed to exist in markets, but subject to different constraints", namely political and bureaucratic ones (Veljanovski 2010). And so "the essential idea that policymakers are for sale, and that the regulatory policy is largely purchased by those most interested and able to buy it, remains central to the literature" (Carpenter and Moss 2014) - even if several assumptions made by Laffont and Tirole (1991) have been considerably relaxed by European political scientists interested in the "politics of delegation" (Thatcher and Stone Sweet 2004). Throughout the 2000s, the different approaches to economic regulation complexified due to "a growing interest in various regulatory strategies and motivations" (Baldwin et al. 2010). As a result, a broader conception of the source of regulatory power gradually emerged.

These developments have challenged these general conceptions as scepticism has grown over whether principal-agent accounts are a good proxy for regulatory politics. A number of empirical and theoretical contributions have started questioning the idea that the politics of regulation can be modelled as a vertical and hierarchical relation involving a firm, an agent, and political principals seeking to avoid bureaucratic "drift" or "slack" and regulatory capture.

At the heart of this scepticism lies the observation that regulatory agencies evolve in "richly textured" political environments "composed of diverse audiences, including elected officials, clientele groups, the media, policy experts, and ordinary citizens" (Carpenter and Krause 2012). These highly networked ecosystems consist of a variety of institutional actors, communicative structures, and accountability relationships (Black 2008). By engaging into various interactions with these audiences, agencies seek to maintain "broad- 
based support" for their activities, in order to secure their survival (Carpenter and Krause 2012). According to this conception, principal-agent based accounts capture a very limited aspect of the politics of economic regulation, since they fail to account for the "fragmentation, complexity and interdependences" that characterize the daily operations of regulatory agencies (Maggetti and Papadopoulos 2018).

Many empirical contributions have confirmed and expanded on this general statement. Maor and Sulitzeanu-Kenan (2012), for instance, have demonstrated that as media coverage of U.S “Food and Drug Administration's (FDA) consumer protection responsibilities becomes more positive, the agency takes enforcement decisions more slowly; in contrast, more critical media coverage leads to quicker action by the FDA". This finding echoes Carpenter (2002), who has shown that FDA drug review times are decreasing according to "the wealth and the richest organization representing the disease treated by the drug", the "media coverage given to the disease" and "a non-linear function of the number of groups representing this disease $\sqrt{6}$. In their analysis of interactions between the British Financial Ombudsman Service (FOS) and financial firms, the media, consumers, politicians, and the Financial Services Authority, Gilad and Yogev (2012) have argued "that regulators are inclined to self-bind, formalise, and rationalise their use of discretion when facing or perceiving high risks to their reputation". This body of research suggests that the kind of politics in which regulatory agencies are engaged resembles the politics of legitimacy or reputation more than principal-agent accounts would indicate. This has recently led to a number of theoretical refinements to better reflect how regulators actually behave.

In this vein, Busuioc and Lodge $(2016 ; 2017)$ have recently provided a broader understanding of regulation. Following Carpenter (2001; 2010a), they argued that agencies'

\footnotetext{
${ }^{6}$ See also Culpepper (2011) for a discussion on political salience, backdoor politics and corporate control.
} 
behaviour is actually motivated by a general concern for their reputation. This term refers to "a set of beliefs about an organization's capacities, intentions, history, and mission that is embedded in a network of multiple audiences" (Carpenter 2010a). As a multifaceted concept, reputation can be performative (the ability of an agency to "do the job"); moral (the ability of an agency to protect its constituents or the general public); procedural (the ability of an agency to follow "normally accepted rules and norms"); or technical (the ability of an agency to deploy the "capacity and skills required for dealing in complex environments") (Carpenter and Krause 2012).

According to this framework, the protection or enhancement of organizational reputation "drive the way in which account-givers and account-holders relate to each other" (Busuioc and Lodge 2017). Regulatory agencies present different faces to different actors, engaging in a constant balancing of their core reputational assets - and the same applies to their multiple audiences. Principals' and agents' activities should therefore not be regarded as reducing information asymmetries, mitigating agency loss, or avoiding bureaucratic drift and slack. Under this framework, the accountability relationship is first and foremost about "being seen as a reputable actor in the eyes of one's audience(s), conveying the impression of competently performing one's roles, thereby generating reputational benefits" (Busuioc and Lodge 2016).

This framework and its many underlying assumptions more fundamentally suggest that the politics of regulation are about much more than formal provisions and a limited range of self-serving goals. The motivations, implications, and effects of the proactive engagement of regulators in wider "forums" 7 also need to be considered. By doing so, regulators not only regulate firms each time a product needs to be assessed, or each time an action must be "rewarded" or "punished" (Braithwaite 2002). The politics of

\footnotetext{
${ }^{7}$ See Schillemans and Busuioc 2015 for a recent discussion of this notion.
} 
regulation is also about how a regulatory agency, in the course of the regulatory process, or in its interactions with its audiences, helps "define what sorts of problems, debates and agendas" structure the activities of different audiences (Carpenter 2010a). Several empirical contributions specifically focusing on the relationship between firms and regulators have explicitly sought to refine the understanding of regulatory power on this basis.

According to Carpenter (2010a), the FDA's gatekeeping power accounts for the relatively few controversies that have emerged from the drug development process in the U.S. The regulator's reputation is simply too strong for a firm to risk submitting a substandard product, since a negative decision could significantly affect its own reputation. "Out of fear of rejection or stringency at the FDA", Carpenter states, "sponsors abandon hundreds if not thousands of new therapeutic ideas every year. These hard cases never appear before the Administration, and so its officials need not deal with the contentious issues they involve". Stressing the "dialectic unity" of the regulators and the regulated (Mügge 2010), Thiemann (2018a) significantly nuanced capture-based accounts in his study on the growth of shadow-banking. National interventions, he argued, are shaped by a wide range of factors, including "the domestic regulatory culture, the regulatory institutional setup [...] and the national legal framework". In turn, this explains why "not all banking regulators were equally permissive". Contrasting France with the U.S, the Netherlands, and Germany, he notably showed that the French regulator intervened early on to "close the regulatory loopholes that allowed banks to engage in risk-taking activity".

These studies also helped dispel the common idea that firms are driven by purely economic considerations, while regulatory agencies and their principals in government are motivated by "political" concerns. Often shaped by government-business relations, iden- 
tity and beliefs structure the strategies of firms and their representatives, as Woll (2008) has argued in her study of regulatory reforms in telecommunication and air transportation. Both firms and regulatory authorities therefore tend to fight over the definition and prioritization of a common set of values and ideas. This is what Smith (2016) explicitly suggests in his recent study of pharmaceutical regulation in France.

These same contributions have helped transcend the capture thesis in its simplest form. Indeed, the emphasis placed on larger regulatory spaces, analysed through a more granular conception of regulatory power, has shed light on the many institutional settings exhibiting "shared regulatory authority across private and public actors" (Baldwin et al. 2010). The findings have also overtaken Stigler's argument. While many statistical correlations have been established between measures of regulatory policy and indicators of the strength of a certain interest, a number of contributions have revealed that such correlations might have arisen "under a regulatory regime that was neutral or designed with non-capture purposes in mind" (Carpenter 2010b). Scholars using more sophisticated mathematical models of regulation notably advanced this argument (see Carpenter 2004; Carpenter et al. 2010). Several contributions with a similar perspective suggest that capture has been frequently over-diagnosed (see Carpenter and Moss 2014; chapters 8 to 11). In many situations, evidence of capture in the Stiglerian sense (and even in the sense of Laffont and Tirole) is missing. Others have suggested that the perceived success of interest groups can itself be an outcome of a governmental or regulatory strategy to advance the public interest (see Woll 2007).

\subsection{Regulation as an order of concepts}

The study of the 'forging' (Carpenter 2001) of regulators' autonomy and the 'dialectic unity' (Mügge 2010) of firms and regulators in broader 'accountability' spaces (Busuioc 
and Lodge 2017) has also led several scholars to discover another facet of regulatory power, namely its ability to impose its own cognitive framework of regulatory issues.

Carpenter (2010a) clearly grasped and defined conceptual power in his study of U.S pharmaceutical regulation. He showed that the FDA's repeated contact with a broad set of audiences allowed it to "shape fundamental patterns of thought, communication and learning by its formal and informal definitions of concepts, vocabularies, measurements and standards". A case in point is the three-phased clinical trials that firms are required to deploy in order to test their products before licensing. The trials are based on a range of metrics that define hierarchies between 'good' and 'bad' products; they encapsulate in a dedicated statistical vocabulary what might be considered as 'toxic' or not, and how to measure the 'placebo effect', among many other terms and devices (see also Carpenter 2010b). Gradually ingrained in everyday business practice, these concepts then came to shape the very understanding these firms have of their environment, and their strategy development. But the influence of this conceptual order is not limited to firms. Over time, FDA agents' policies have also influenced entire segments of medical and health sciences. They are also reflected in many other areas, such as in political discourses or media coverage of pharmaceutical policy. They also structure the strategies of other actors, such as financial investors. Conceptions of pharmaceuticals as a public matter evolved accordingly. "If public and financial debates about a product depend heavily upon statistical measurements that the regulator has fashioned or championed", Carpenter (2010a) notes, "then the regulator's power is exercised and felt well outside its walls".

Readers familiar with the literature on state theory and political development will certainly recognize here a very well-established feature of 'stateness', namely its "constitutive role", which lies in its tendency to establish "terms with common meanings, 
thereby giving people new categories by which to orient themselves" (Pettit 2008) - a building block of King and Stears' "theory of standardization" (King and Stears 2011). Contrary to the directive, and to a lesser extent gatekeeping, dimensions of power, regulation here is not considered in terms of its most obvious and visible effects on human agency. Instead, it is viewed in terms of how it defines and builds a series of contexts wherein "agency is both authorized and enacted" (Hay 2014).

Interest in the conceptual facet of regulatory power has helped to both connect research on regulation with additional areas of political research, and to explore the legitimacy and diffusion of regulatory standards in global contexts. Benoît (2018) has for instance observed that the regulatory instruments and vocabulary of one single national agency (England's National Institute for Health and Clinical Excellence, NICE) are now used by a number of transnational pharmaceutical companies to define their R\&D policy and their market-access strategies. To account for this situation, Benoît showed how the political work of this agency's experts led to the legitimization of their regulatory standards in various international forums. This initiative then generated emulation within the industry, which in turn influenced the behaviour of transnational companies and their relations with other national regulators. This echoes the findings of research in international political economy emphasizing the role of expert communities in shaping the standards used and diffused by transnational organizations (see Seabrooke and Nilsson 2014 for a recent illustration on financial surveillance).

One of the older topics in the study of regulation - regulatory capture - is also increasingly being theorized in a similar fashion. Kwak (2013) has identified three mechanisms "by which regulated industry is able to shape regulators' beliefs and actions". Together, they form a distinct form a capture, namely 'cultural' capture in Kwak's terms. The first mechanism he identified is identity: "regulators are more likely to adopt positions 
advanced by people whom they perceive as being in their in-group". A second factor

is status. Regulators, Kwak argued, "are more likely to adopt positions advanced by people whom they perceive to be of higher status in social, economic, intellectual, or other terms". The third factor is relationship, based on the assumption that regulators are more easily subject to the influence of individuals in their social networks. This approach sheds light on the formation of consensual views on certain issues between firms and regulators despite the absence of proof of materialistic capture. In several situations, a common understanding of a given situation by firms, regulators, and experts across private and public spheres might lead to the persistence of certain regulatory arrangements, sometimes in the interest of industry. An example is the case of international financial stability, as studied by Seabrooke and Tsingou (2009). Private risk management persisted in this area because of its legitimacy in "different professional ecologies" (regulators, academics and private risk managers), and involved revolving door phenomena (see Thiemann 2018b for a discussion).

\section{Conclusion}

What is 'new' in the political analysis of economic regulation? And, more fundamentally, what so political about economic regulation? This article has argued that the answer to both of these questions lies in the conception of power used in different political analyses of this topic.

Research informed by agency theory significantly expanded our understanding of the politics of regulation. One of its major contributions was to show how diverse actors drive this activity (firms, interest groups, regulators, and legislators, among others), and how information asymmetries are key to understanding their interactions. This helped 
establish a number of connections between scholars of regulation and scholars of interest groups, legislatures, and legislative behaviour.

However, most of these works were based on an essentially directive conception of regulatory power. More recently, a greater focus on the building of regulatory agencies' legitimacy and their relations with their wider environment, has highlighted the many ways in which regulators shape public policy and industrial behaviour. The growing interest in the 'gatekeeping' facet of regulatory power has also shed light on the importance of "understanding regulation as communication and as a network" (Baldwin et al. 2010). A deeper focus on how regulatory concepts "shape the content and structure of human cognition itself" (Carpenter 2010a) also helped connect studies on the politics of regulation with the findings of other political science literature, ranging from as state theory to international political economy. Where to go from here? The various contributions reviewed in this article have already opened a number of promising paths to be further explored. An obvious and crucial issue for research in the field is now to better understand the articulation between the three facets of regulatory power, and the way they relate to one another. At a finer level of analysis, we think that there are at least three topics that have not yet received the scholarly attention they deserve.

The first relates to the various reasons why audiences 'trust' their regulator. Thanks to many of the aforementioned contributions, we know a lot more about how and by what means regulators engage with diverse audiences to secure their support. What is less known are the conditions under which these audiences recognize such attempts to legitimize agencies' activities. Such recognition is likely to differ across audiences and contexts. It is also likely to be highly contingent. More systematic comparisons and analyses are therefore needed on this point. Carpenter (2010b) identified a second, related topic. It concerns the "origins and patterns of consumer and citizen beliefs 
about markets, and in particular the effect of regulation upon these beliefs". One of the most important transformations described in this article is a gradual shift in the literature from a conception of regulation in terms of 'politics of interest' to a conception in terms of 'politics of legitimacy'. Much-needed studies on why and how citizens trust in markets shaped or protected by regulation could also build a bridge between regulation scholarship and another segment of political research, namely that on institutional trust.

A third topic relates to how regulatory concepts, regulatory influence, and regulatory decisions are perceived, and how they influence debates and conflicts in wider political arenas. What role do regulatory issues play in electoral campaigns - and how does a regulator's reputation affect the outcome? How does the same variable affect the likelihood that political parties will stake positions on regulatory issues? And in turn, how is a regulator's reputation affected by the electoral salience of its policy area? Several studies have already provided some preliminary answers to these questions. But what is lacking here is deeper analysis to more systematically analyse them. Together, the pursuit of these three research agendas could further our understanding of regulatory power, not only as politics of interests, but first and foremost as politics of legitimacy.

\section{References}

Aberbach, J., Putnam, R. and Rockman, B. (1981) Bureaucrats and Politicians in Western Democracies, Cambridge: Harvard University Press.

Armstrong, M. and Sappington, D. (2007) "Recent Developments in the Theory of

Regulation", in Schmalensee, R., Armstrong, M. Willig, R. and Porter, R. (eds.) Handbook of Industrial Organization vol. 3, Amsterdam: North Holland.

Arrow, K. (1985) "The Economics of Agency", in Pratt, J. and Zeckhauser, R. (eds.) 
Principals and Agents: the structure of Business, Cambridge: Harvard University Press.

Bach, T., Hammershmid, G. and Löffler, L. (2018) "More Delegation, More Political Control? Politicization of Senior-Level Appointments in 18 countries", Public Policy and Administration, Online version.

Baldwin, R., Cave, M. and Lodge, M. (2010) "Introduction: Regulation, the field and the developing agenda" in Baldwin, R., Cave, M. and Lodge, M. (eds.) The Oxford Handbook of Regulation, Oxford: Oxford University Press.

Baldwin, R. Cave, M. and Lodge, M. (2012) Understanding Regulation: Theory, Strategy and Practice, Oxford: Oxford University Press.

Baldwin, R., Scott, C. and Hood, C. (1998), 'Introduction', in Bardwin, R., Scott, C. and Hood, C. (eds), A Reader on Regulation, Oxford: Oxford University Press.

Black, J. (2008) "Constructing and Contesting Legitimacy and Accountability in Polycentric Regulatory Regimes", Regulation \& Governance, 2(2): 137-164.

Braithwaite, J. (2002) "Rewards and Regulation", Journal of Law and Society, 29(1): $12-26$.

Braithwaite, J. (2011) "The Regulatory State?", in Goodin, E. (ed.) The Oxford Handbook of Political Science, Oxford: Oxford University Press.

Benoît, C. (2018) "Le pouvoir de régulation transnational d'une agence nationale", Gouvernement \& Action Publique, 5(1): 9-32.

Benoit, C. (forth.) "Legislatures and the Administrative State: Political Control, Bureaucratic Politics and Public Accountability", in Benoît, C. and Rozenberg, O. (eds.) Handbook of Parliamentary Studies: Interdisciplinary Approaches to Legislatures, Cheltenham: Edward Elgar.

Buchanan, J.M and Tullock, G. (1962) The Calculus of Consent: Logical Foundations of Constitutional Democracy, Ann Arbor: University of Michigan Press. 
Busuioc, M. and Lodge, M. (2016) "The Reputational Basis of Public Accountability", Governance, 29(2): 247-263.

Busuioc, M. and Lodge, M. (2017) "Reputation and Accountability Relationships: Managing Accountability Expectations through Reputation", Public Administration Review, 77(1): 91-100.

Calvert, R.L, Moran, M.J. and Weingast, B. (1987) "Congressional Influence Over Policymaking: The case of the FTC', in McCubbins M. and Sullivan T. (eds.) Congress: Structure and Policy, New York: Cambridge University Press.

Carpenter, D. (2001) The Forging of Bureaucratic Autonomy: Reputations, Networks and Policy Innovation in Executive Agencies 1862-1928, Princeton: Princeton University Press.

Carpenter, D. (2002) "Groups, the Media, Agency, Waiting Costs, and FDA Drug Approval", American Journal of Political Science, 46(3): 490-505.

Carpenter, D. (2004) "Protection without Capture: Product Approval by a Politically Responsive, Learning Regulator", American Political Science Review, 98(4): 613-631.

Carpenter, D. (2010a) Reputation and Power: Organizational Image and Pharmaceutical Regulation at the FDA, Princeton: Princeton University Press.

Carpenter, D. (2010b) "Confidence Games: How Does Regulation Constitute Markets?", in Balleisen, E. and Moss, D. (eds.) Governments and Markets: Towards a New Theory of Regulation, New York: Cambridge University Press.

Carpenter, D. (2014) "Detecting and Measuring Capture", in Carpenter, D. and Moss, D. (eds.) Preventing Regulatory Capture: Special Interest Influence and How to Limit it, New York: Cambridge University Press.

Carpenter, D., Grimmer, J. and Lomazoff, E. (2010) "Approval Regulation and Endogenous Consumer Confidence: Theory and Analogies to Licensing, Safety and Finan- 
cial Regulation", Regulation \& Governance, 4(4): 383-407.

Carpenter, D. and Krause, G. (2014) "Reputation and Public Administration", Public Administration Review, 72(1): 26-32.

Carpenter, D. and Moss, D. (2014) (eds.) Preventing Regulatory Capture: Special Interest Influence and How to Limit it, New York: Cambridge University Press.

Carpenter, D. and Moss, D. (2014) "Introduction", in Carpenter, D. and Moss, D. (eds.) Preventing Regulatory Capture: Special Interest Influence and How to Limit it, New York: Cambridge University Press.

Carrigan, C. and Coglianese, C. (2015) "George Stigler, 'The Theory of Economic Regulation'", in Lodge, M., Page, E. and Balla, S. (eds.) The Oxford Handbook of Classics in Public Policy and Administration, Oxford: Oxford University Press.

Christensen, J. (2011) "Competing Theories of Regulatory Governance: Reconsidering Public Interest Theory of Regulation", in Levi-Faur, D. (ed.) Handbook on the Politics of Regulation, Cheltenham: Edward Elgar.

Coletti, P. and Radaelli, C. (2013) "Economic Rationales, Learning, and Regulatory Policy Instruments", Public Administration, 91(4): 1056-1070.

Culpepper, P. (2011) Quiet Politics and Business Power: Corporate Control in Europe and Japan, Cambridge: Cambridge University Press.

Dal Bó, E. (2006) "Regulatory Capture: A Review", Oxford Review of Economic Policy, 22(2): 203- 225.

De Mesquita, E.B. and Stephenson, M. (2007) "Regulatory Quality Under Imperfect Oversight", American Political Science Review, 101(3): 605-620.

Downs, A. (1957) An Economic Theory of Democracy, New York: Harper \& Row.

Ennser-Jedenastik, L. (2016) "The Politicization of Regulatory Agencies: Between Partisan Influence and Formal Independence", Journal of Public Administration Research 
and Theory, 26(3): 507.

Frison-Roche, M-A (2004) Droit et économie de la régulation vol.1: les régulations économiques, légitimité et efficacité, Paris: Presses de Sciences Po.

Gailmard, S. (2014) "Accountability and Principal-Agent Models", in Bovens, M., Goodint, T. and Schillemans, T. (eds.), The Oxford Handbook of Public Accountability, Oxford: Oxford University Press, 2014.

Gilad, S. and Yogev, T. (2012) "How Reputation Regulates Regulators: Illustrations from the Regulation of Retail Finance", in Pollock, T. and Barnett, M. (eds.) The Oxford Handbook of Corporate Reputation, Oxford: Oxford University Press.

Gilardi, F. (2008) Delegation in the Regulatory State: Independent Regulatory Agencies in Western Europe, Cheltenham: Edward Elgar.

Gilardi, F., Jordana, J. and Levi-Faur, D. (2006), "Regulation in the Age of Globalization: The Diffusion.of Regulatory Agencies Across Europe and Latin America," in Hodge, G. (ed.), Privatization and Market Development: Global Movements in Public Policy Ideas, Cheltenham: Edward Elgar.

Hankte-Domas, M. (2003) "The Public Interest Theory of Regulation: Non-Existence or Misinterpretation?", European Journal of Law and Economics, 15(2): 165-194.

Hay, C. (2014) "Neither real nor fictitious but 'as if real'? A political ontology of the state", British Journal of Sociology, 65(3): 459-480.

Hood, C., Scott, C., James, O., Jones, G. W., and Travers, A. J. (1999) Regulation Inside Government: Waste-Watchers, Quality Police, and Sleaze-Busters, Oxford: Oxford University Press.

Jordana, J. and Levi-Faur, D. (2005a) "The Making of a New Regulatory Order", Annals of the American Academy of Political and Social Sciences, 598: 6-9.

Jordana, J. and Levi-Faur, D. (2006) "Toward a Latin American Regulatory State? 
The Diffusion of Autonomous Regulatory Agencies Across Countries and Sectors", International Journal of Public Administration, 29(4-6): 335-366.

Kwak, J. (2013) "Cultural Capture and the Financial Crisis", in Carpenter, D. and Moss, D. (eds.) Preventing regulatory capture: Special interest influence and how to limit it, New York: Cambridge University Press.

Kiewiet, D. and McCubbins, M. (1991) The Logic of Delegation: Congressional Parties and the Appropriations Process, Chicago: University of Chicago Press.

King, D. and Stears, M. (2011) "How the US State Works: A Theory of Standardization", Perspective on Politics, 9(3): 505-518.

Koop, C. and Lodge, M. (2017) "What is Regulation? An Interdisciplinary Concept Analysis", Regulation \& Governance, 11(1): 95-108.

Laffont, J-J and Tirole, J. (1990) "The Politics of Government Decision-Making: Regulatory Institutions", Journal of Law, Economics and Organizations, 6(1): 1-31.

Laffont, J-J and Tirole, J. (1991) "The Politics of Government Decision-Making: A Theory of Regulatory Capture", The Quarterly Journal of Economics, 106(4): 1089-1127.

Laffont, J-J and Tirole, J. (1993) A Theory of Incentives and Procurement in Regulation, Cambridge: MIT Pres.

Levi-Faur, D. (2005) "The Global Diffusion of Regulatory Capitalism", Annals of the American Academy of Political and Social Science, 598: 12-32.

Levi-Faur, D. (2014) "The Welfare State: A Regulatory Perspective", Public Administration, 92(3): 599-614.

Lowi, T. (1969) The End of Liberalism. The Second Republic of the United States, New York: Norton.

Lowi, T. (1972) "Four Systems of Policy, Politics and Choice", Public Administration Review, 32(4): 298-310. 
Maggetti, M. and Papadopoulos, Y. (2018) "The Principal-Agent Framework and Independent Regulatory Agencies", Political Studies Review, 16(3): 172-183.

Majone, G. (1994) "The Rise of Regulatory State in Europe", West European Politics, 17(3): 77-101.

Maor, M. and Sulitzeanu-Kenan, R. (2012) "The Effect of Salient Reputational Threats on the Pace of FDA Enforcement", Governance, 26(1): 31-61.

McCubbins, M. (1985) "The Legislative Design of the Regulatory Structure", American Journal of Political Science, 29(4): 721-748.

McCubbins, M. (2014) "Common Agency? Legislatures and Bureaucracies", in Martin et al. (eds.) The Oxford Handbook of Legislative Studies, Oxford: Oxford University Press.

McCubbins, M. and Schwartz, T. (1984) "Congressional Oversight Overlooked: Police Patrols versus Fire Alarms", American Journal of Political Science, 28(1): 165-179.

Miller, G. (2005) "The Political Evolution of Principal-Agent Models", Annual Review of Political Science, 8: 203-25.

Moe, T. (1985) "The Politicized Presidency", in Chubb, J. and Peterson, P. (eds.) The New Direction in American Politics, Washington: Brooking Institution.

Moe, T. (1987a) "Control and Feedback in Economic Regulation: the case of the NLRB", American Political Science Review, 79(4): 1094-1116.

Moe, T. (1987b) "An Assessment of the Positive Theory of Congressional Dominance", Legislative Studies Quarterly, 12(4): 475-520.

Moran, M. (2003) The British Regulatory State: High Modernism and Hyper-Innovation, Oxford: Oxford University Press.

Mügge, D. (2010) Widen the Market, Narrow the Competition: Banker Interests and the Making of a European Capital Market, Colchester: ECPR Monographs. 
Niskanen, W. (1971) Bureaucracy and Representative Government, Chicago: Aldine \& Atherton.

Noll, R. (1989) "Economics Perspectives on the Politics of Regulation", in Willig, R. and Schmalensee, R. (eds.) Handbook of Industrial Organization vol. 2, Amsterdam: North Holland.

Olson, M. (1965) The Logic of Collective Action, Cambridge: Harvard University Press.

Ossege, C. (2016) European Regulatory Agencies in EU Decision-making, Basingstoke: Palgrave. Pettit, P. (2008) Made with words: Hobbes on language, Mind and Politics, Princeton: Princeton University Press.

Pollack, M. (2002) "Learning from the Americanists (Again): Theory and Method in the study of Delegation", West European Politics, 25(1): 200-219.

Seabrooke, L. and Nilsson, E. (2014) "Professional Skills in International Financial Surveillance: Assessing Change in IMF Policy Teams", Governance, 28(2): 237-254.

Seabrooke, L. and Tsingou, E. (2009) "Revolving Doors and Linked Ecologies in the World Economy: Policy Locations and the Practice of International Financial Reform", CSGR Working Paper 260 (09), 1-29.

Schillemans T and Busuioc M (2015) "Predicting Public Sector Accountability: From Agency Drift to Forum Drift", Journal of Public Administration Research and Theory, 25(1): 191-215.

Shleifer, A. (2005) "Understanding Regulation", European Financial Management, 11(4): 439-451.

Stigler, G. (1971) "The Theory of Economic Regulation", The Bell Journal of Economics and Management Sciences, 2(1): 3-21.

Smith, A. (2016) "The Economics Driven by Politics as Values: The Example of 
Pharmaceuticals in France", New Political Economy, 22(6): 611-627.

Thatcher, M. (2002) "Regulation After Delegation: Independent Regulatory Agencies in Europe", Journal of European Public Policy, 9(6): 954-972.

Thatcher, M. (2007) "Regulatory Agencies, the State and the Market: A FrancoBritish comparison", Journal of European Public Policy, 14(7): 1028-1047.

Thatcher, M. (2011) "The creation of European Regulatory Agencies and its limits: a comparative analysis of European delegation", Journal of European Public Policy, 18(6): $790-809$.

Thatcher, M. and Stone Sweet, A. (eds.) (2003) The Politics of Delegation, London: Franck Cass.

Thiemann, M. (2018a) The Growth of Shadow Banking. A Comparative Institutional Analysis, Cambridge, Cambridge University Press.

Thiemann, M. (2018b) "Régulation des marchés financiers", dans Hay, C. and Smith, A. (eds.) Dictionnaire d'économie politique, Paris : Presses de Sciences Po.

Tirole, J. (1986) "Hierarchies and Bureaucracies: on the Role of Collusion in Organizations", Journal of Law, Economics and Organizations, 2(2): 181-214.

Veljanovski, C. (2010) "Economic Approaches to Regulation" in Baldwin, R., Cave, M. and Lodge, M. (eds.) The Oxford Handbook of Regulation, Oxford: Oxford University Press.

Weingast, B.R. (1984) "The Congressional Bureaucratic System: A Principal-Agent perspective", Public Choice, 44(1): 147-191.

Weingast, B.R. and Moran, M.J. (1983) "Bureaucracy Discretion or Congressional Control? Regulatory Policymaking by the Federal Trade Commission", Journal of Political Economy, 91(5): 765-800.

Whitford, A. (2005) "The Pursuit of Political Control by Multiple Principals", The 
Journal of Politics, 67(1): 29-49.

Woll, C. (2007) "Leading the Dance? Power and Political Resources of Business Lobbyists", Journal of Public Policy, 27(1): 57-78.

Woll, C. (2008) Firm Interests: How Governments Shape Business Lobbying in Global Trade, Ithaca: Cornell University Press.

Yeung, K. (2010) "The Regulatory State" in Baldwin, R., Cave, M. and Lodge, M. (eds.) The Oxford Handbook of Regulation, Oxford: Oxford University Press. 